\title{
Trichomes and chemical composition of the volatile oil of Trichogonia cinerea (Gardner) R. M. King \& H. Rob. (Eupatorieae, Asteraceae)
}

\author{
YANNE S. FERNANDES ${ }^{1}$, LUMA M.P. TRINDADE ${ }^{1}$, MARIA HELENA \\ REZENDE ${ }^{1}$, JOSÉ R. PAULA ${ }^{2}$ and LETÍCIAA. GONÇALVES ${ }^{1}$ \\ ${ }^{1}$ Universidade Federal de Goiás, Instituto de Ciências Biológicas, Departamento de Botânica, \\ Avenida Esperança, s/n, Campus Samambaia, 74690-900 Goiânia, GO, Brasil \\ ${ }^{2}$ Universidade Federal de Goiás, Faculdade de Farmácia, Rua 240, Esquina com quinta \\ Avenida, s/n, Setor Leste Universitário, 74605-170 Goiânia, GO, Brasil
}

Manuscript received on December 3, 2014; accepted for publication on September 28, 2015

\begin{abstract}
Trichogonia cinerea is endemic to Brazil and occurs in areas of cerrado and campo rupestre. In this study, we characterized the glandular and non-glandular trichomes on the aerial parts of this species, determined the principal events in the development of the former, and identified the main constituents of the volatile oil produced in its aerial organs. Fully expanded leaves, internodes, florets, involucral bracts, and stem apices were used for the characterization of trichomes. Leaves, internodes, florets, and involucral bracts were examined by light microscopy and scanning electron microscopy, whereas stem apices were examined only by light microscopy. Branches in the reproductive phase were used for the extraction and determination of the composition of the volatile oil. The species has three types of glandular trichomes, biseriate vesicular, biseriate pedunculate, and multicellular uniseriate, which secrete volatile oils and phenolic compounds. The major components identified in the volatile oil were 3,5-muuroladiene (39.56\%) and butylated hydroxytoluene (13.07\%).
\end{abstract}

Key words: volatile oil, histochemistry, ontogeny, secretory structure.

\section{INTRODUCTION}

Trichomes are unicellular or multicellular appendages, which originate only from epidermal cells, develop outwards on the surface of various plant organs, and can be found on all parts of the plant. Their major distinction is between glandular and non-glandular trichomes. The trichomes that differ in type and/or location probably also differ in other, not always investigated, properties and

Correspondence to: Letícia de Almeida Gonçalves

E-mail: leticia.icb.ufg@gmail.com in function (Werker 2000). Plants may need protection from various external factors, such as herbivores, pathogens, extensive light, and extreme temperatures. Therefore, densely spread nonglandular trichomes may serve as a mechanical barrier against most of the aforementioned factors (Werker 2000). Moreover, glandular and nonglandular trichomes are an important first line of defense against herbivorous insects (Werker 2000, Glas et al. 2012) and the glandular trichomes may serve as a chemical protection against pathogens (Blakeman and Atkinson 1979, Werker 2000). 
In addition to the ecological importance of trichomes, their characterization may also contribute to taxonomic studies, and the morphology of glandular and non-glandular trichomes is of great importance for systematic studies, at different taxonomic levels, of the Asteraceae. Narayana (1979) suggested that trichomes can be a diagnostic character in Vernonia Schreb.; whereas Wagner et al. (2014) used the diversity of non-glandular trichomes to make taxonomic differentiations in subtribe Lychnophorinae (Vernonieae). Despite the wide variety of glandular trichomes, biseriate glandular trichomes are typical of the Asteraceae (Metcalfe and Chalk 1950) and biseriate trichomes are present in several species of the tribes Astereae, Eupatorieae, Heliantheae, Inuleae, Mutisieae, and Vernonieae (Cortadi and Gattuso 1994, Castro et al. 1997, Cortadi et al. 1999). Furthermore, species of the tribes Eupatorieae and Heliantheae frequently have uniseriate glandular trichomes (Castro et al. 1997).

Chemically complex mixtures, composed almost entirely of terpenes and phenylpropenes, called volatile oils (Waterman 1993), are commonly found in species of Asteraceae. It is noteworthy that the volatile oils produced by many species of this family have proven to exhibit antimicrobial (Neerman 2003) and insecticide activity (Campos et al. 2014). Bohlmann et al. (1981) conducted chemosystematic studies of the tribe Eupatorieae and analyzed the sesquiterpene lactones and other constituents of Trichogonia species to determine if their chemical composition could give indications of the relationships among the species of this diverse genus.

The name of the genus Trichogonia refers to the characteristic setulae on the angles of the fruits (King and Robinson 1987), and the presence of glandular stipitate trichomes on the corolla tube is an important feature in the taxonomy of this genus (Roque et al. 2012). Among the 20 recognized species of Trichogonia, 17 occur in Brazil. The species can be classified into two groups, one has heads presenting convex receptacles and glandular stipitate trichomes on the corolla tube, and the other, which includes most species, is characterized by flat receptacles and glabrous corolla tube (Roque et al. 2012).

Trichogonia cinerea (Gardner) R. M. King \& H. Rob. is endemic to Brazil and belongs to the first group described above, with convex receptacles and glandular stipitate trichomes on the corolla tubes. The species is found in the states of Bahia and Goiás, as well as in the Distrito Federal, where has been collected in areas of cerrado and campo rupestre (Roque et al. 2012). Although the trichomes are clearly visible on the aerial organs (reproductive and vegetative), their characterization has not been performed yet. In the current study, we aimed to characterize the glandular and nonglandular trichomes on the aerial parts of $T$. cinerea using light microscopy and scanning electron microscopy (SEM) to identify the main events in their development. Additionally, the composition of the volatile oil produced in the aerial organs of this species was determined.

\section{MATERIALS AND METHODS}

Samples of $T$. cinerea were collected in areas of cerrado rupestre $\left(16^{\circ} 04.613^{\prime} \mathrm{S}, 50^{\circ} 11.318^{\prime} \mathrm{W}\right.$ and $\left.16^{\circ} 04.712^{\prime} \mathrm{S}, 50^{\circ} 11.481^{\prime} \mathrm{W}\right)$ in the state of Goiás, Brazil. Plants in the vegetative and reproductive phases as well as seeds were collected in April 2012 for the study of trichomes. For the volatile oil analyses, fertile branches were collected at $11 \mathrm{am}$ in April 2013, with registered precipitation of $96 \mathrm{~mm}$, minimum and maximum temperatures of $21^{\circ} \mathrm{C}$ and $33^{\circ} \mathrm{C}$, respectively, and relative humidity of $71 \%$ (INMET 2013). A voucher specimen was deposited at the UFG herbarium (accession number 3994), acronyms according to Thiers 2013 (continuously updated).

For the characterization of trichomes, fully expanded leaves from the third to the fifth node (from apex to base), samples from the second to the fifth internodes (from apex to base), stem 
apices, disc florets, and involucral bracts were used. Fragments from the middle third of both the petiole and the leaf blade were collected. For the ontogenetic study of glandular trichomes, stem apices were harvested from young plants obtained by germinating seeds. Some leaf and internode samples were free-hand cut transversely, some were mounted in historesin, and some others were examined by scanning electron microscopy (SEM). Florets and involucral bracts were analyzed using SEM, and stem apices were mounted in paraffin. The samples used for histochemical analyses were processed immediately after collection and those used for light microscopy were fixed in FAA 50 and stored in 70\% ethanol (Johansen 1940), while samples used for SEM were fixed by immersion in a modified Karnovsky's solution (Karnovsky 1965).

Free-hand cut leaf and internode sections were double-stained with a $1: 3$ solution of $0.1 \%(\mathrm{w} / \mathrm{v})$ basic fuchsin and $0.3 \%(\mathrm{w} / \mathrm{v})$ astra blue, modified from Roeser (1972), and the clarified samples were stained with $1 \%(\mathrm{w} / \mathrm{v})$ aqueous safranin solution. The material was then mounted on slides in $50 \%$ $(\mathrm{v} / \mathrm{v})$ aqueous solution of glycerin. For inclusion in historesin samples were dehydrated in a graded ethyl alcohol series, kept in a pre-infiltration solution for three days, and in an infiltration solution for seven days. Samples were infiltrated with hydroxyethyl methacrylate historesin (HistoResin Plus, ReichertJung, Heidelberg, Germany). The resulting blocks were cut into $10-\mu \mathrm{m}$ thick sections using a rotary microtome Leica RM2245 (Leica Biosystems Nussloch GmbH, Nußloch, Germany) and stained with toluidine blue (O’Brien et al. 1964).

Seeds were germinated in plastic pots with sandy soil collected from areas naturally colonized by $T$. cinerea and watered periodically. Stem apices were collected 70 days after seed germination, from plants around 2.5 to $3.0 \mathrm{~cm}$ tall and with two pairs of leaves. Apices were dehydrated in an ethylalcohol to xylol series and embedded in paraffin (Johansen 1940). The resulting blocks were cut into $12-\mu \mathrm{m}$ thick longitudinal sections using a rotary microtome Leica RM2245, deparaffinized, and stained with ferric hematoxylin (Sass 1951) and a $1: 3$ solution of $0.1 \%(\mathrm{w} / \mathrm{v})$ basic fuchsin and $0.3 \%$ (w/v) astra blue (modified from Roeser 1972).

Historesin and paraffin sections were mounted in colorless glass varnish Acrilex ${ }^{\circledR} 500 \circledR$ (Acrilex Tintas Especiais S/A, São Bernardo do Campo, SP, Brazil, according to Paiva et al. (2006). In the histochemical analyses we used Lugol's iodine solution to detect starch, acidified phloroglucinol to reveal the presence of lignin in cellular walls, sudan III for total lipids, ferrous sulphate, ferric chloride (Johansen 1940), and potassium dichromate (Gabe 1968) for phenolic compounds, bromophenol blue (Mazia et al. 1953) and coomassie blue (Fisher 1968) for proteins, Dittmar's reagent (Furr and Mahlberg 1981) for alkaloids, and NADI reagent (David and Carde 1964) for volatile oil. Photomicrographs of the sections were taken using a Leica ICC50 HD microscope camera attached to a Leica DM500 optical microscope and the software LAS EZ for image acquisition (Leica Microsystems $\mathrm{GmbH}$, Heerbrugg, Switzerland).

The samples for SEM were dehydrated in an ethyl alcohol series, critical-point dried with liquid carbon dioxide $\left(\mathrm{CO}_{2}\right)$, and coated with gold in a Denton Vacuum Sputter Coater (Denton Vacuum, LLC, Moorestown, NJ, USA). The samples were analyzed using a scanning electron microscope JSM-6610 (JEOL Ltd, Tokyo, Japan), operated at 4 Kv, equipped with a Thermo Scientific NSS spectral imaging system (Thermo Fischer Scientific Inc., Madison, WI, USA) for energy-dispersive X-ray spectroscopy (EDS) at the Laboratório Multiusuário de Microscopia de Alta Resolução (LabMic), in the Instituto de Física of the Universidade Federal de Goiás (UFG), in Goiânia, GO, Brazil.

The branches used for oil analysis were stored in plastic containers under refrigeration for $12 \mathrm{~h}$. After this period, the material was fragmented, gathered in a sample of $110 \mathrm{~g}$, and submitted to hydrodistillation using a Clevenger-type apparatus for $3 \mathrm{~h}$ (Brasil 1988). The volume of oil obtained 
was determined using the volumetric tube of the equipment. The determination of the chemical constituents of the oil was performed by gas chromatography-mass spectrometry (GC/MS), using a Shimadzu QP5050A (Shimadzu Co., Kyoto, Japan), a fused-silica capillary column (CBP $5 ; 30 \mathrm{~m} \times 0.25 \mathrm{~mm} ; 0.25 \mu \mathrm{m}$ film thickness), at a flow rate of $1 \mathrm{~mL} / \mathrm{min}$ of helium as the carrier gas, heating at pre-programmed temperatures $\left(60^{\circ} \mathrm{C}\right.$ for $2 \mathrm{~min}$, increasing to $240^{\circ} \mathrm{C}$ at a rate of $3^{\circ} \mathrm{C} / \mathrm{min}$, followed by heating up to $280^{\circ} \mathrm{C}$ at a rate of $10^{\circ} \mathrm{C} / \mathrm{min}$, and maintained at this temperature for $10 \mathrm{~min}$ ), and an ionization voltage of $70 \mathrm{eV}$. The chemical compounds were identified using the NIST/EPA/NIH Mass Spectral Library 2011 and by comparison of their retention indices and mass spectra with those of authentic compounds (Adams 2007). The retention indices were calculated by co-injecting a commercial $\mathrm{C} 8-\mathrm{C} 32$ aliphatic hydrocarbons mixture (Sigma-Aldrich Co. LLC, St. Louis, MO, USA) and the equation of van Den Dool and Kratz (1963).

\section{RESULTS}

Cross-sections of leaves, stems, involucral bracts, and florets (Figs. 1-3) allowed the identification of glandular trichomes, herein classified into three types: biseriate vesicular (Figs. 1a, 2a), formed by four pairs of cells; biseriate pedunculate (Figs. $1 b, 2 b$ ), with two to five pairs of cells forming the stalk and four to five pairs of secretory cells on the head; and multicellular uniseriate, curved towards the epidermis (Figs. 1c, 2c), with four to six cells forming the stalk and a unicellular head. In biseriate vesicular glandular trichomes, the cuticle over the secretory head expands (Figs. 1a, 2a), forming a large subcuticular space that corresponds to the
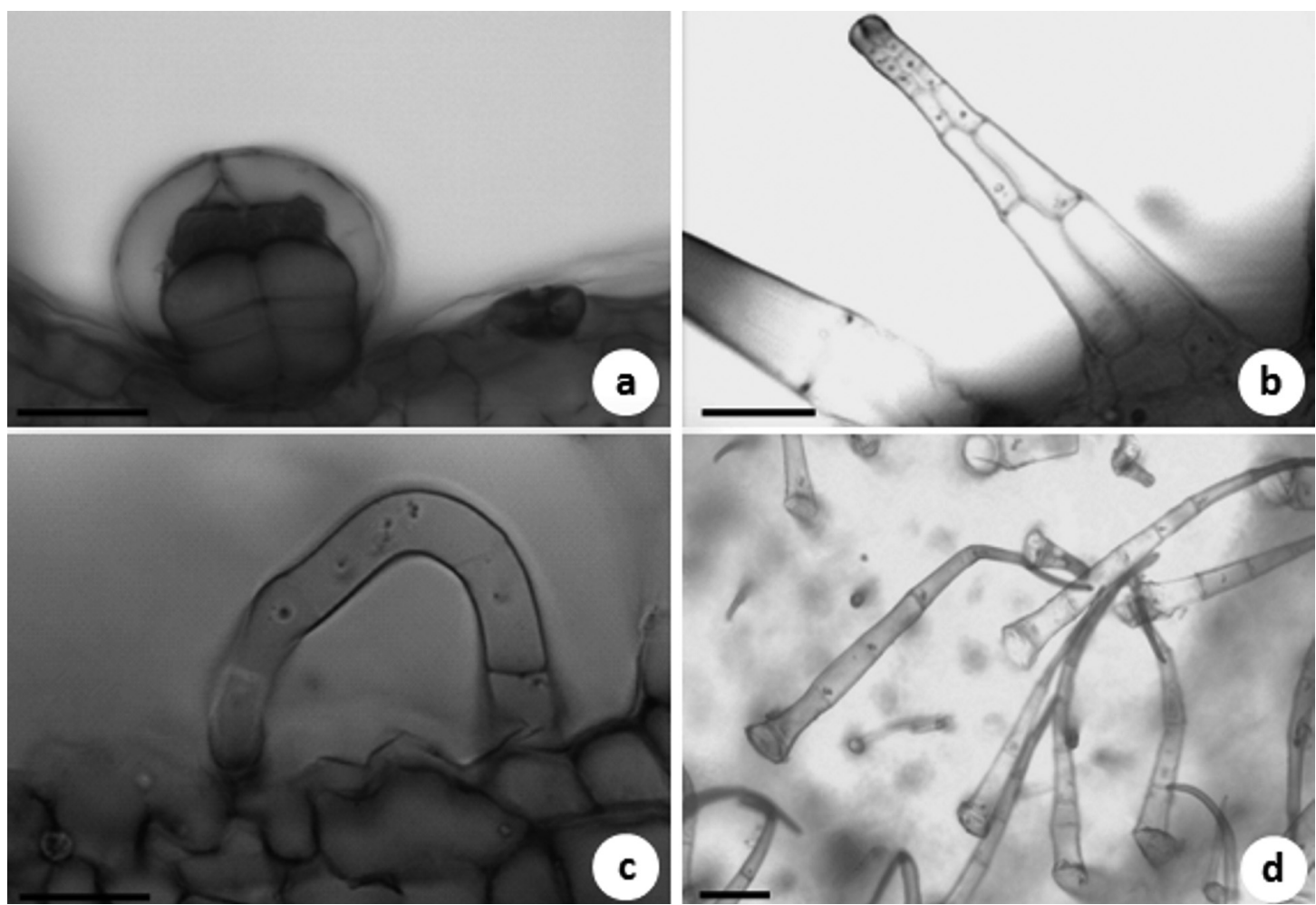

Figure 1 - Glandular (a-c) and non-glandular (d) trichomes on aerial organs of Trichogonia cinerea (Gardner) R. M. King \& H. Rob. (a) Biseriate vesicular glandular trichome. (b) Biseriate pedunculate glandular trichome. (c) Multicellular uniseriate glandular trichome curved towards the epidermis. (d) Non-glandular trichomes on involucral bracts. Scale bars: $\mathbf{a}$ and $\mathbf{c}=50 \mu \mathrm{m} ; \mathbf{b}=100 \mu \mathrm{m} ; \mathbf{d}=500 \mu \mathrm{m}$. 
storage site of secreted material. This space was not observed in the other types of trichome. In addition to the glandular trichomes, we found non-glandular trichomes on all the structures analyzed (Fig 1d and Figs 2d-e), which are multicellular uniseriate, with a variable number of cells (2-5), voluminous cells at the base, and a tapering apical cell. All trichome types are found of the leaf blade, petiole, and stem (Fig. 2f), where the biseriate vesicular glandular trichomes are found in small depressions of the epidermis. The florets are densely covered by glandular and non-glandular trichomes (Fig. 3a),
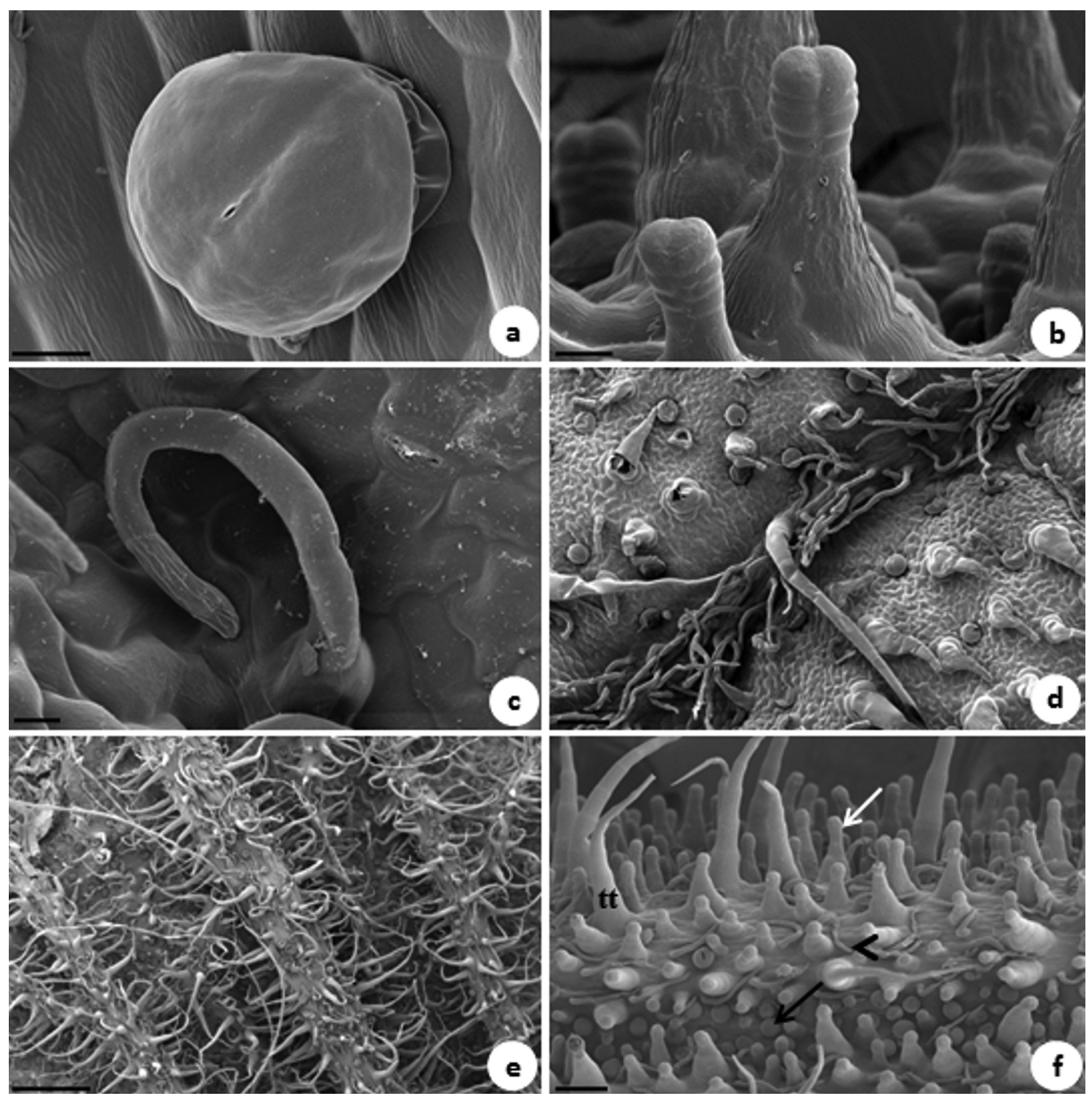

Figure 2 - Images of glandular and non-glandular trichomes of Trichogonia cinerea (Gardner) R. M. King \& H. Rob. acquired using scanning electron microscopy (SEM). (a-e) Trichomes on the leaves. (a) Biseriate vesicular glandular trichome on the abaxial surface, with distended cuticle. (b) Biseriate pedunculate glandular trichome on the abaxial surface. (c) Multicellular uniseriate glandular trichome on the adaxial surface. (d) General view of the adaxial surface. (e) General view of the abaxial surface densely covered by non-glandular trichomes. (f) Trichomes on the stem. Biseriate vesicular glandular trichomes (black arrow), biseriate pedunculate glandular trichomes (white arrow), multicellular uniseriate glandular trichomes (white arrowhead), and non-glandular trichomes (tt). Scale bars: $\mathbf{a}$ and $\mathbf{c}=$ $10 \mu \mathrm{m} ; \mathbf{b}=20 \mu \mathrm{m} ; \mathbf{d}$ and $\mathbf{f}=100 \mu \mathrm{m} ; \mathbf{e}=500 \mu \mathrm{m}$. 
although only biseriate pedunculate and biseriate vesicular glandular trichomes were observed (Figs. 3b-c). The corolla has biseriate pedunculate trichomes and the ovary has vesicular glandular trichomes. All types of glandular trichomes are present on the involucral bracts (Figs. 3d-e). Nonglandular trichomes are present on the corolla (Fig. 3f) and involucral bracts.
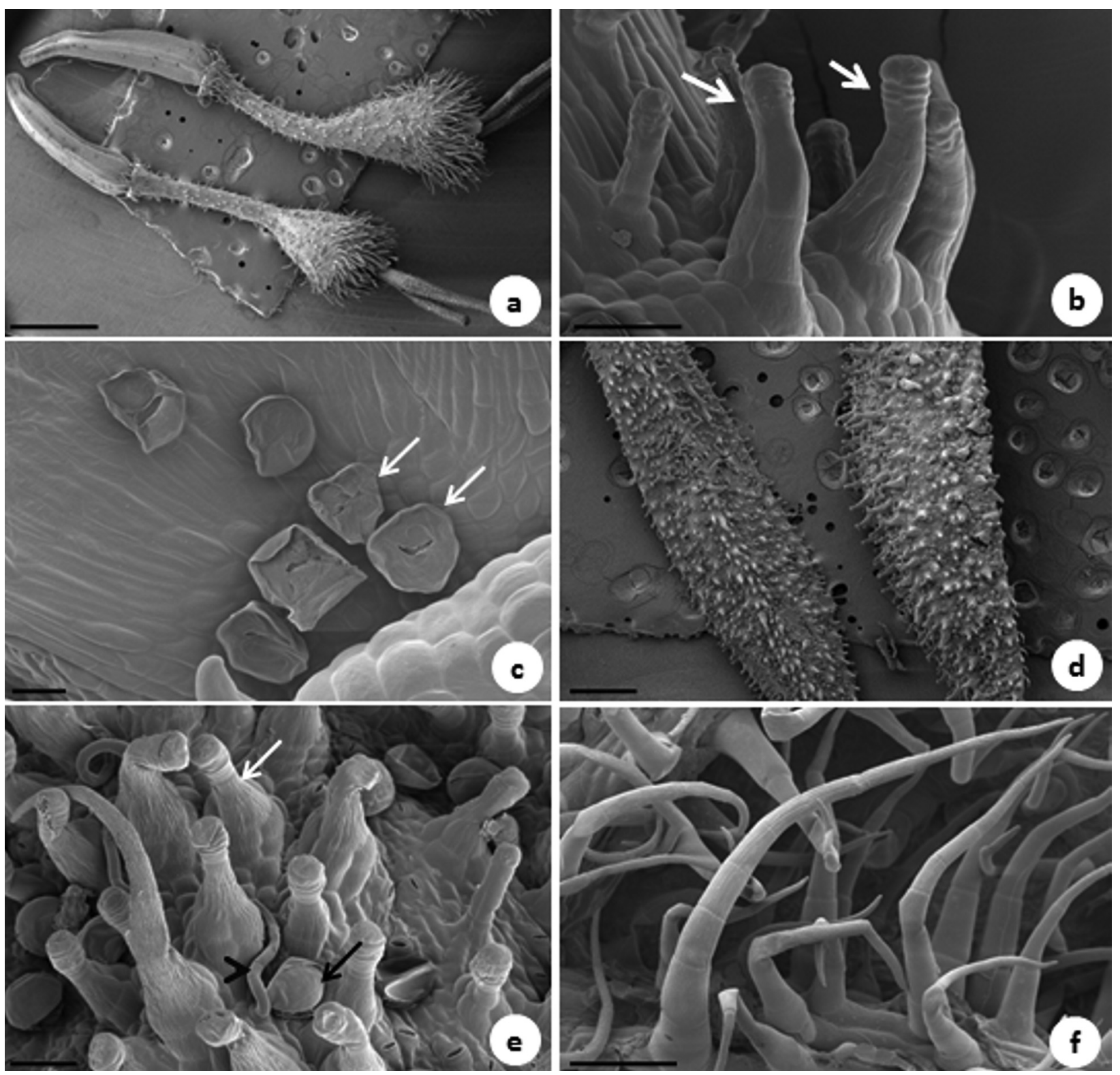

Figure 3 - Images of glandular and non-glandular trichomes on florets (a-c and f) and involucral bracts (d-e) of Trichogonia cinerea (Gardner) R. M. King \& H. Rob. acquired using scanning electron microscopy (SEM). (a) General aspect of the florets showing the petals densely covered by glandular and non-glandular trichomes. (b) Biseriate pedunculate glandular trichomes at the insertion of the petals on the ovary (white arrows). (c) Biseriate vesicular glandular trichomes on the ovary (white arrows). (d) General aspect of the involucral bracts densely covered by glandular and non-glandular trichomes. (e) Details of a biseriate vesicular glandular trichome (black arrow), a biseriate pedunculate glandular trichome (white arrow), and a multicellular uniseriate glandular trichome (black arrowhead). (f) Non-glandular trichomes. Scale bars: $\mathbf{a}=1000 \mu \mathrm{m} ; \mathbf{b}=50 \mu \mathrm{m} ; \mathbf{c}=20 \mu \mathrm{m} ; \mathbf{d}=500 \mu \mathrm{m}$; $\mathbf{e}=30 \mu \mathrm{m} ; \mathbf{f}=100 \mu \mathrm{m}$. 
The secretions of glandular trichomes of $T$. cinerea are naturally yellow, and chloroplasts can be observed inside the secretory cells. The results of the histochemical analyses are shown in Table I. Sudan III test revealed total lipids within the subcuticular space of biseriate vesicular glandular trichomes, in the secretory cells of biseriate pedunculate, and in the stalk and secretory cells of multicellular uniseriate trichomes. Phenolic compounds were detected in all three types of glandular trichomes using ferrous sulphate and potassium dichromate, and in biseriate vesicular trichomes using ferric chloride. The presence of volatile oil was confirmed using Nadi reagent, which formed blue droplets in the subcuticular space of biseriate vesicular trichomes, in the secretory cells of biseriate pedunculate trichomes, and in the stalk and secretory cells of multicellular uniseriate trichomes.

Glandular and non-glandular trichomes are present on the hypocotyl, epicotyl, and cotyledons of $T$. cinerea. Glandular trichomes in various stages of development can be observed on the stem apex (Fig. 4a). The first stage of differentiation, with the expansion of a protodermal cell, is shared by all three types of glandular trichomes. In biseriate vesicular trichomes, the protodermal cell expands and increases in volume (Fig. 4b), then undergoes an anticlinal division to originate two cells (Fig. 4c). These cells expand synchronously, and the resulting cells undergo successive periclinal divisions (Figs. 4d-e). In multicellular uniseriate trichomes, the protodermal cell becomes curved as it expands (Fig. 4f), which is followed by successive periclinal divisions (Figs. 4g-i).

Differentiation of the biseriate pedunculate glandular trichome begins with a single expanded protodermal cell, which is voluminous and has dense contents (Fig. 5a). This cell undergoes anticlinal division, originating two cells (Fig. 5b) that undergo periclinal divisions (Fig. 5c). This is followed by successive non-synchronized periclinal divisions of the cells in each of the two series (Figs. 5d-f). Since the divisions are not synchronized, at the end of the differentiation phase the cells may occupy different heights (Fig. 5g).

The yield of the volatile oil isolated from the fertile branches of $T$. cinerea was $0.09 \%(\mathrm{v} / \mathrm{w})$. The volatile oil was composed of 19 constituents, representing $73.93 \%$ of the total oil, and their percentages are listed in Table II. The sesquiterpenes were the most abundant $(60.19 \%)$ compound,

TABLE I

Results of histochemical tests used in the glandular trichomes of Trichogonia cinerea (Gardner) R. M. King \& H. Rob. collected in an area of cerrado rupestre, in the state of Goiás, Brazil.

\begin{tabular}{|c|c|c|c|c|c|c|}
\hline \multirow{3}{*}{ Reagent } & \multicolumn{6}{|c|}{ Glandular trichomes* } \\
\hline & \multicolumn{2}{|c|}{ Biseriate vesicular } & \multicolumn{2}{|c|}{ Biseriate pedunculate } & \multicolumn{2}{|c|}{ Multicellular uniseriate } \\
\hline & SS & $\mathrm{SC}$ & $\mathrm{SC}$ & $\mathrm{S}$ & $\mathrm{SC}$ & $\mathrm{S}$ \\
\hline Lugol's iodine & - & - & - & - & - & - \\
\hline Acidified phloroglucinol & - & - & - & - & - & - \\
\hline Sudan III & + & _ & + & _ & + & + \\
\hline Ferrous sulphate & + & + & + & + & + & + \\
\hline Potassium dichromate & + & + & + & + & + & + \\
\hline Ferric chloride & + & + & - & - & - & - \\
\hline Bromophenol blue & - & - & - & - & - & - \\
\hline Coomassie blue & - & - & - & - & - & - \\
\hline Dittmar's reagent & - & - & - & - & - & - \\
\hline NADI reagent & + & - & + & - & + & + \\
\hline
\end{tabular}

SS - subcuticular space, SC - secretory cells, S - stalk; (-) - negative results; $(+)$ - positive results. 

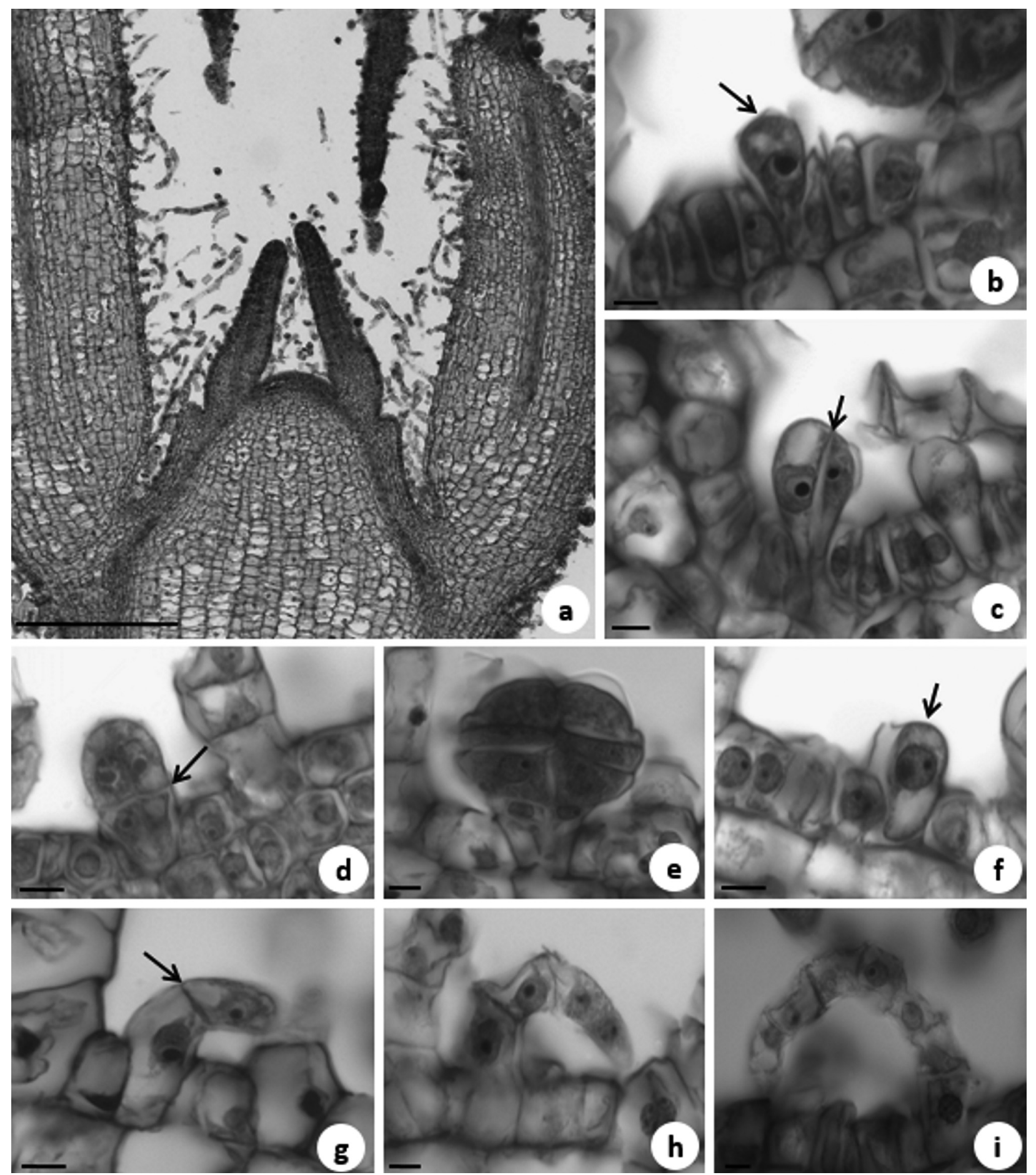

Figure 4 - Ontogenetic events of Trichogonia cinerea (Gardner) R. M. King \& H. Rob. biseriate vesicular glandular and multicellular uniseriate glandular trichomes. (a) General view of the stem apex with trichomes undergoing differentiation. (b-e) Developmental events of biseriate vesicular glandular trichomes. (b) Expanded protodermal cell (arrow) with a voluminous nucleus. (c) Anticlinal division (arrow) of the expanded protodermal cell. (d) Synchronized periclinal divisions (arrow). (e) Short biseriate vesicular glandular trichomes in the final stage of differentiation. (f-i) Developmental events of glandular multicellular uniseriate trichomes. (f) Expanded protodermal cell (arrow) with a voluminous nucleus. (g) First periclinal division, already with curved cells (arrow). (h-i) Products of successive periclinal divisions (arrows). Scale bars: $\mathbf{a}=500 \mu \mathrm{m} ; \mathbf{b}-\mathbf{i}=10 \mu \mathrm{m}$. 

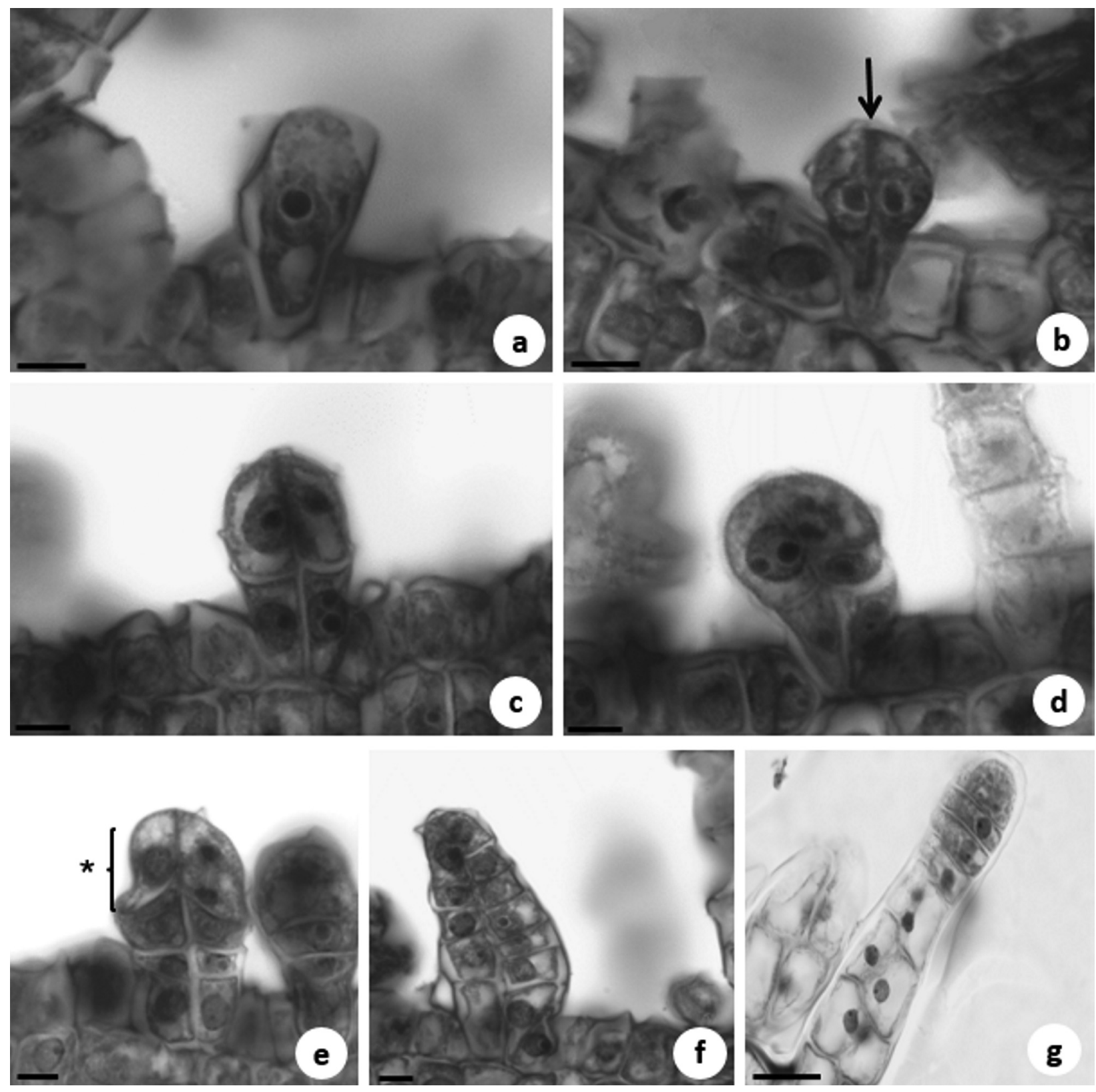

Figure 5 - Ontogenetic events of Trichogonia cinerea (Gardner) R. M. King \& H. Rob. biseriate pedunculate glandular trichomes. (a) A voluminous protodermal cell with dense contents. (b) Anticlinal division (arrow) of the expanded protodermal cell. (c) First periclinal divisions of cell series. (d) Non-synchronized periclinal divisions of the cell series. (e) Distal cells of the trichome $(*)$ in different stages of differentiation. (f) Trichome with numerous non-synchronized periclinal divisions. (g) Biseriate pedunculate glandular trichome in the last stage of differentiation. Scale bars: $\mathbf{a - f}=10 \mu \mathrm{m} ; \mathbf{g}=50 \mu \mathrm{m}$.

with $54.22 \%$ sesquiterpene hydrocarbons, $5.97 \%$ oxygenated sesquiterpenes, $3.99 \%$ sesquiterpene alcohols and $13.07 \%$ phenolic alcohol (butylated hydroxytoluene). The major component was 3,5 -muuroladiene, in a total of $39.56 \%$. The second and the third most abundant components were butylated hydroxytoluene $(13.07 \%)$ and $E$-caryophillene $(5.63 \%)$, respectively, whereas oxygenated monoterpene represented only $0.67 \%$ of the total oil content. 
TABLE II

Chemical constituents of the volatile oil of aerial organs of Trichogonia cinerea (Gardner) R. M. King \& H. Rob. from an area of cerrado rupestre, in the state of Goiás, Brazil.

\begin{tabular}{lcc}
\hline Chemical constituent $^{\text {a }}$ & KI & \% \\
\hline terpinenen-4-ol & 1177 & 0.67 \\
silphiperfol-5-ene & 1328 & 0.8 \\
silphiperfol-6-ene & 1379 & 0.99 \\
modhelf-2-ene & 1383 & 0.4 \\
cyperene & 1398 & 0.31 \\
$\beta$-isocomene & 1408 & 0.66 \\
E-caryophillene* & 1419 & 5.63 \\
3,5-muuroladiene* & 1450 & 39.56 \\
$\alpha$-humulene & 1454 & 1.76 \\
bicyclogermacrene & 1500 & 1.31 \\
$\alpha$-muurolene & 1500 & 0.43 \\
-amorphene & 1512 & 1.27 \\
butylated hydroxytoluene* & 1515 & 13.07 \\
7-epi- $\alpha$-selinene & 1522 & 1.10 \\
E-nerodiol & 1563 & 0.39 \\
caryophyllene oxide & 1583 & 1.69 \\
epi- $\alpha$-cadinol & 1640 & 1.85 \\
allo-aromadendrene epoxide- & 1641 & 0.29 \\
$\alpha$-muurolol & 1646 & 1.75 \\
\hline Total identified & & 73.93 \\
\hline Oxygenated monoterpenes & & 0.67 \\
Sesquiterpene hydrocarbons & & 54.22 \\
Oxygenated sesquiterpenes & & 5.97 \\
Sesquiterpene alcohols & & 3.99 \\
Phenolic alcohol & & 13.07 \\
\hline - & &
\end{tabular}

${ }^{\text {a }}$ Listed according to the order of elution.

* Major constituents.

KI - Kovats retention indices (Adams 2007); \% - percentage of compounds obtained by gas chromatography-mass spectrometry (GC/MS).

\section{DISCUSSION}

Trichogonia cinerea presents biseriate and uniseriate glandular trichomes, which results in dense indumentum on the leaves. Some evidence suggests that this dense indumentum formed by nonglandular and/or glandular trichomes represents an adaptation to habitats with low water availability and high temperatures (Werker 2000). Furthermore, Manetas (2003) showed that trichomes protect plant tissues against damage by UV-B rays.

The individuals of $T$. cinerea assessed in the present study were collected in cerrado rupestre, which has shallow sandy soils and high incidence of solar radiation, coupled with a long dry season during the year. Thus, the indumentum formed by the dense cover of non-glandular and glandular trichomes is likely to be important for water economy and protection of chlorophyllous tissues against high temperatures and intense solar radiation, improving $\mathrm{CO}_{2}$ assimilation during unfavorable periods. Furthermore, the elimination of secondary metabolites by glandular trichomes may provide chemical protection against herbivores and pathogens (Werker 2000, Glas et al. 2012). 
The biseriate vesicular glandular trichomes of T. cinerea are similar to those found on the aerial organs of other Asteraceae species and several aspects of these structures have been investigated (Ascensão and Pais 1987, Figueiredo and Pais 1994, Afolayan and Meyer 1995, Pagni 1995, Castro et al. 1997, Ascensão et al. 2001, Heinrich et al. 2002, Andreucci et al. 2008, Oliveira et al. 2013, Trindade et al. 2014).

Uniseriate trichomes curved towards the epidermis occur in several species of the tribes Eupatorieae (Cortadi and Gatuso 1994, Castro et al. 1997, Trindade et al. 2014) and Heliantheae (Castro et al. 1997, Duarte and Empinotti 2012). The occurrence of curved glandular trichomes is shared by the tribes Eupatorieae and Heliantheae, and provides evidence of a possible affinity between them (Castro et al. 1997). This type of trichome is also found in Eupatoruim macrocephalum Less., E. inulaefolium H.B.K., and E. subhastatum Hook et Arn (Cortadi and Gatuso 1994). Also, biseriate pedunculate glandular trichomes have been registered in several species of the tribe Eupatorieae (Castro et al. 1997, Trindade et al. 2014).

As already mentioned, the species of Trichogonia can be classified into two groups, and T. cinerea, T. eupatorioides, T. hassleri, and T. prancei belong to the first one, with convex receptacles and glandular stipitate trichomes on the corolla tubes (Roque et al. 2012). The results of the present study showed that the stipitate trichomes that occur on the corolla in $T$. cinerea are biseriate pedunculate and that, in addition to these, tector trichomes were also observed. Further studies are necessary in order to characterize the glandular trichomes found on the corolla of the other species of this group.

In $T$. cinerea, biseriate glandular trichomes develop from a single protodermal cell that divides anticlinally. This development is similar, in several aspects, to that of Madia sativa Molina (Carlquist 1958), Artemisia campestris ssp. maritima L. (Ascensão and Pais 1987), Artemisia annua L. (Duke and Paul 1993), Stevia rebaudiana (Bert.) Bert. (Monteiro et al. 2001), Helianthus annuus L. (Amrehn et al. 2014), and Lomatozona artesimiifolia Baker (Trindade et al. 2014). The ontogenetic events of uniseriate trichomes, on the other hand, are similar to those of Helichrysum aureonitens Sch. Bip. (Afolayan and Meyer 1995).

Secretions from glandular trichomes of T. cinerea contain volatile oils and phenolic compounds, a chemical composition that is common in the Asteraceae (Aguilera et al. 2004, Fonseca et al. 2006). The content of volatile oil produced by $T$. cinerea was low and the major fraction of the constituents identified was composed of sesquiterpenes. Sesquiterpenoids are typical metabolites of Asteraceae species (Seaman 1982) and are used in the chemotaxonomy of the family (Bohlmann et al. 1981, Seaman 1982, Zdero and Bohlmann 1990). It is worth to emphasize that some of the constituents identified in this study present therapeutic potential. Sesquiterpene bicyclogermacrene, for instance, exhibited antifungal activity when isolated (Silva et al. 2007), whereas $(E)$-caryophillene showed antibacterial activity (Garg and Siddiqui 1992, Formisano et al. 2006).

\section{CONCLUSION}

T. cinerea has two types of biseriate and one type of uniseriate glandular trichomes on the leaves, stems, and involucral bracts. In contrast, only biseriate glandular trichomes are found on the corolla. The three types of trichomes secrete volatile oils and phenolic compounds. The glandular trichomes differentiate at the stem apices from a protodermal cell that expands and acquires a voluminous aspect. In biseriate glandular trichomes, the first division of the expanded protodermal cell is anticlinal, while in the multicellular uniseriate trichome this division is periclinal. Most of the components of the volatile oil from $T$. cinerea identified in the present study are sesquiterpenes. Taking into consideration that 
the morphology of glandular trichomes and the chemical composition of volatile oils is of great importance for the Asteraceae, the results obtained in this study may help further taxonomic studies of this family at different taxonomic levels.

\section{ACKNOWLEDGMENTS}

The authors would like to thank the Coordenação de Aperfeiçoamento de Pessoal de Nível Superior (CNPq) for the financial support through a fellowship, the Laboratório Multiusuário de Microscopia de Alta Resolução (LabMic) of the Universidade Federal de Goiás (UFG) for the SEM analyses, and Dr. Aristônio Magalhães Teles for determining the species.

\section{RESUMO}

Trichogonia cinerea é endêmica no Brasil e ocorre em áreas de Cerrado e campo rupestre. Neste estudo, foram caracterizados os tricomas glandulares e não glandulares das partes aéreas dessa espécie, determinados os principais eventos no desenvolvimento dos primeiros e identificados os principais constituintes do óleo volátil produzido em seus órgãos aéreos. Folhas completamente expandidas, entrenós, flores, brácteas involucrais e ápices caulinares foram utilizados para a caracterização dos tricomas. Folhas, entrenós, flores e brácteas involucrais foram examinados em microscópio de luz e microscópio eletrônico de varredura, enquanto ápices caulinares foram examinados somente em microscópio de luz. Ramos, em fase reprodutiva, foram usados para a extração e a determinação da composição do óleo volátil. A espécie tem três tipos de tricomas glandulares, bisseriados vesiculosos, bisseriados pedunculados e unisseriados pluricelulares, que secretam óleos voláteis e compostos fenólicos. Os principais componentes identificados no óleo volátil foram 3,5-muuroladieno $(39,56 \%)$ e hidroxitolueno butilado (13,07\%).

Palavras-chave: óleo volátil, histoquímica, ontogênese, estrutura secretora.

\section{REFERENCES}

ADAMS RP. 2007. Identification of essential oil components by gas chromatography/mass spectrometry, $4^{\text {th }}$ ed., Illinois: Allured Publishing Corporation, 804 p.
AFOLAYAN AJ AND MEYER JJM. 1995. Morphology and ultrastructure of secreting and nonsecreting foliar trichomes of Helichrysum aureonitens (Asteraceae). Int J Plant Sci 156: 481-487.

AgUilerA DB, MEIRA RMSA AND FERREIRA FA. 2004. Anatomia e histoquímica dos órgãos vegetativos de Siegesbeckia orientalis (Asteraceae). Planta Daninha 22: 483-489.

Amrehn E, Heller A And Spring O. 2014. Capitate glandular trichomes of Helianthus annuus (Asteraceae): ultrastructure and cytological development. Protoplasma 251: 161-167.

ANDREUCCI AC, CICCARELLI D, DESIDERI I AND PAGNI AM. 2008. Glandular hairs and secretory ducts of Matricaria chamomilla (Asteraceae): Morphology and histochemistry. Ann Bot Fenn 45: 11-18.

ASCENSÃO L AND PAIS MSS. 1987. Glandular trichomes of Artemisia campestris (ssp. maritima): ontogeny and histochemistry of the secretory product. Bot Gaz 148: 221227.

Ascensão L, Silva JAT, Barroso JG, Figueiredo AC AND PEDRO LG. 2001. Glandular trichomes and essential oils of Helichrysum stoechas. Isr J Plant Sci 49: 115-122.

BLAKEMAN JP AND ATKINSON P. 1979. Antimicrobial properties and possible role in host-pathogen interactions of parthenolide, a sesquiterpene lactone isolated from glands of Chrysanthemum parthenium. Physiol Plant Pathol 15: 183-190.

BOHLMANN F, ZDERO C, PICKARD J, ROBINSON H AND KING RM. 1981. New types of sesquiterpene lactones and other constituents from Trichogonia species. Phytochemistry 20: 1323-1333.

BRASIL. 1998. Ministério da Saúde. Métodos de Farmacognosia. Determinação de óleos essenciais. In: ANVISA. Farmacopéia brasileira, $4^{\mathrm{a}}$ ed., São Paulo: Atheneu Editora São Paulo, Parte 1, 392 p.

CAMPOS ACT, RADÜNZ LL, RADÜNZ AL, MOSSI AJ, DIONELLO RG AND ECKER SL. 2014. Atividade repelente e inseticida do óleo essencial de carqueja doce sobre o caruncho do feijão. Rev Bras Eng Agríc Ambient 18: 861865.

CARLQUIST S. 1958. Structure and ontogeny of glandular trichomes of Madinae (Compositae). Am J Bot 45: 675682.

CASTRO MM, LEITÃO-FILHO HF AND MONTEIRO WR. 1997. Utilização de estruturas secretoras na identificação dos gêneros de Asteraceae de uma vegetação de cerrado. Rev Bras Bot 20: 163-174.

CORTAdi A, Di-SAPio O, MCCARGo J, ScAndizzi A, GATTUSO S AND GATTUSO M. 1999. Anatomical studies of Baccharis articulata, Baccharis crispa and Baccharis trimera, "Carquejas" used in folk medicine. Pharm Biol 37: $357-365$ 
CORTADI AA AND GATTUSO MA. 1994. Caracterización anatómica e histoquímica de Eupatorium macrocephalum Less., E. inulaefolium H.B.K. y E. subhastatum Hook et Arn. Asteraceae. Dominguezia 11: 32-42.

DAVID R AND CARDE JP. 1964. Coloration différentielle des inclusions lipidiques et terpéniques des pseudophylles du Pin maritime au moyen du réactif Nadi. C R Hebdo Séances Acad Sci 258: 1338-1340.

DUARTE MR AND EMPINOTTI CB. 2012. Leaf and stem microscopic identification of Tithonia diversifolia (Hemsl.) A. Gray (Asteraceae). Braz J Pharm Sci 48: 109-116.

DUKE SO AND PAUL RN. 1993. Development and fine structure of the glandular trichomes of Artemisia annua $\mathrm{L}$. Int J Plant Sci 154: 107-118.

FIGUEIREDO AC AND PAIS MSS. 1994. Ultrastructural aspects of the glandular cells from the secretory trichomes and from the cell suspension cultures of Achillea millefolium L. ssp. millefolium. Ann Bot 74: 179-190.

FISHER DB. 1968. Protein staining of ribboned epon sections for light microscopy. Histochemie 16: 92-96.

FONSECA MCM, MEIRA RMSA AND CASALI VWD. 2006. Anatomia dos órgãos vegetativos e histolocalização de compostos fenólicos e lipídicos em Porophyllum ruderale (Asteraceae). Planta Daninha 24: 707-713.

Formisano C, SENATORE F, BRUno M AND BELlone G. 2006. Chemical composition and antimicrobial activity of the essential oil of Phlomis ferruginea Ten. (Lamiaceae) growing wild in Southern Italy. Flavour Frag J 21: 848851.

FURR Y AND MAHLBERG PG. 1981. Histochemical analyses of lacticifers and glandular trichomes in Cannabis sativa. $\mathrm{J}$ Nat Prod 44: 153-159.

GABE M. 1968. Techniques histologiques. Paris: Masson \& Cie, $1113 \mathrm{p}$.

GARG SC AND SIDDIQUI N. 1992. Antifungal activity of some essential oil isolates. Pharmazie 47: 467-468.

GLAS JJ, SCHIMMEL BCJ, ALBA JM, ESCOBAR-BRAVO R, SCHUURINK RC AND KANT MR. 2012. Plant glandular trichomes as targets for breeding or engineering of resistance to herbivores. Int J Mol Sci 13: 17077-17103.

HEINRICH G, PFEIFHOFER HW, STABENTHEINER E AND SAWIDIS T. 2002. Glandular hairs of Sigesbeckia jorullensis Kunth (Asteraceae): morphology, histochemistry and composition of essential oil. Ann Bot 89: 459-469.

INMET - Instituto NACiOnAl DE Metrologia. 2013. Ministério da Agricultura, Pecuária e Abastecimento. Brasília, DF. http://www.inmet.gov.br/portal/index. php?r=home/page\&page=rede_estacoes_auto_graf. Accessed October 3, 2013.

JOHANSEN DA. 1940. Plant microtechnique, $2^{\text {nd }}$ ed., New York: McGraw-Hill, 523 p.

KARNOVSKY MJ. 1965. A formaldehyde-glutaraldehyde fixative of high osmolality for use in electron microscopy. J Cell Biol 27: 137-138.
KING RM AND ROBINSON H. 1987. The genera of the Eupatorieae (Asteraceae). Monographs in Systematic Botany, v. 22. Saint Louis: Missouri Botanical Garden, $581 \mathrm{p}$.

MANETAS Y. 2003. The importance of being hairy: the adverse effects of hair removal on stem photosynthesis of Verbascum speciosum are due to solar UV-B radiation. New Phytol 158: 503-508.

MAZIA D, BREWER PA AND ALFERT M. 1953. The cytochemical staining and measument of protein with mercuric bromophenol blue. Biol Bull 104: 57-67.

MetCalfe CF AND CHalK L. 1950. Anatomy of the dicotyledons: leaves, stem and wood in relation to taxonomy with notes on economic uses, Oxford: Clarendon Press. v. 2.

MONTEIRO WR, CASTRO MM, MAZZONI-ViVEIROS SC AND MahlberG PG. 2001. Development and some histochemical aspects of foliar glandular trichomes of Stevia rebaudiana (Bert.) Bert. - Asteraceae. Rev Bras Bot 24: 349-357.

NARAYANA BM. 1979. Taxonomic value of trichomes in Vernonia Schreb. (Asteraceae). Proc Indian Acad Sci 88 347-357.

NEERMAN MF. 2003. Sesquiterpene lactones: a diverse class of compounds found in essential oils possessing antibacterial and antifungal properties. Int J Aromather 13: 114-120.

O'BRIEN TP, FEDER N AND MCCULly ME. 1964. Polychromatic staining of plant cell walls by toluidine blue O. Protoplasma 59: 367-373.

OLIVEIRA T, BOMBO AB AND APPEZZATO-DA-GLÓRIA B. 2013. Anatomy of vegetative organs with an emphasis on the secretory structures of two species of Aldama (Asteraceae-Heliantheae). Botany 91: 335-342.

PAGNI AM. 1995. Secretory structures in the capitula of Santolina leucantha Bertol. (Asteraceae). Morphology and histochemistry. Ann Bot 53: 239-249.

PAIVA JGA, FANK-DE-CARVALhO SM, MaGalHÃES MP AND GRACIANO-RIBEIRO D. 2006. Verniz vitral $500^{\circledR}$ : uma alternativa de meio de montagem economicamente viável. Acta Bot Bras 20: 257-264.

RoESER KR. 1972. Die Nadel der SchwarzkieferMassenprodukt und Kunstwerk der Natur. Mikrokosmos 61: 33-36

RoQUE N, BAUTISTA HP AND MOTA AC. 2012. Taxonomic revision of Trichogonia (Eupatorieae, Asteraceae): a South American genus. Syst Bot 37: 525-553.

SASS JE. 1951. Botanical microtechnique. $2^{\text {nd }}$ ed., Ames: lowa State University Press, 228 p.

SEAMAN FC. 1982. Sesquiterpene lactones as taxonomic characters in the Asteraceae. Bot Rev 48: 121-594.

SILVA L, ONIKI GH, AGRIPINO DG, MORENO PRH, YOUNG MCM, MAYWORM MAS AND LADEIRA AM. 2007. 
Biciclogermacreno, resveratrol e atividade antifúngica em extratos de folhas de Cissus verticillata (L.) Nicolson \& Jarvis (Vitaceae). Rev Bras Farmacog 17: 361-367.

THIERS B. 2013 (continuously updated). Index Herbariorum: A global directory of public herbaria and associated staff. New York Botanical Garden's Virtual Herbarium, New York. http://sweetgum.nybg.org/ih/.

TRINDADE LMP, FERNANDES YS AND GONÇALVES LA. 2014. Diversidade e desenvolvimento dos tricomas glandulares de Lomatozona artemisiifolia Baker (Asteraceae Eupatorieae) - uma planta endêmica do Cerrado de Goiás. Iheringia Sér Bot 69: 235-243.

VAN DEN DOOL H AND KRATZ PD. 1963. Generalization of the retention index system including linear temperature programmed gas-liquid partition chromatography. J Chromatogr A 11: 463-471.
WAGNER MA, LOEUILLE BFP, SINISCALCHI CM, MELO-DEPINNA GF AND PIRANI JR. 2014. Diversity of non-glandular trichomes in subtribe Lychnophorinae (Asteraceae: Vernonieae) and taxonomic implications. Plant Syst Evol 300: 1219-1233.

WATERMAN PG. 1993. The chemistry of volatile oils. In: Hay RKM and Waterman PG (Eds), Volatile oil crops: their biology, biochemistry and production, Harlow: Longman Scientific, p. 47-61.

WERKER E. 2000. Trichome diversity and development. In: Hallahan DL and Gray JC (Eds), Advances in botanical research, incorporating advances in plant pathology, Plant Trichomes, v.31. London: Academic Press, p. 1-35.

ZDERO C AND BOHLMANN F. 1990. Systematics and evolution within the Compositae, seen with the eyes of a chemist. Plant Syst Evol 171: 1-14. 